УДК 631.559:633.11:631.5

(C) 2012

Рожков А. О., кандидат сільськогосподарських наук

Харківський національний аграрний університет ім. В. В. Докучаєва

\title{
ОЦІНКА РОЗВИТКУ ПОСІВІВ ПШЕНИЦІ ЯРӦ̈ ЗА ПРОВЕДЕНИМИ ФЕНОЛОГІЧНИМИ СПОСТЕРЕЖЕННЯМИ
}

\section{Рецензент - доктор сільськогосподарських наук Т. І. Гопцій}

\begin{abstract}
Висвітлено результати чотирирічних досліджень щзодо впливу ценотичних факторів: способів сівби та норм висіву на час проходження окремих фаз розвитку рослин пшениці ярої твердої. У дослідах доведено вплив цеенотичного фактора, щзо визначався різними варіаціями досліджуваних факторів на час проходження рослинами міжфазних періодів розвитку. Із послабленням ценотичної напруги у посівах за смугового способу сівби відзначено прискорене проходження розвитку посівів від сівби до фази кущіння, а також у міжфазний період - від виходу у трубку до иввітіння. Водночас у ичих варіантах відзначено розтягування періоду від повних сходів до виходу в трубку і від иявітіння до воскової стиглості.
\end{abstract}

Ключові слова: иенотична напруга, агрофіточеноз, смуговий спосіб сівби, пшениия яра тверда, онтогенез.

Постановка проблеми. Формування високопродуктивних агрофітоценозів сільськогосподарських культур - складний багатоступеневий процес, у якому беруть участь чимало залежних один від одного чинників на всіх етапах органогенезу, на які по-різному впливають генетичні й екзогенні фактори.

У ході індивідуального розвитку рослин послідовно відбуваються закономірні зміни рослинного організму, що грунтуються на поступовому й поетапному виконанні його спадкової програми розвитку. Пізнання залежностей тривалості формотворчих процесів від впливу агротехнологічних факторів дасть можливість більш повноцінно управляти продукційним процесом пшениці ярої твердої.

Аналіз останніх досліджень і публікацій, у яких започатковано розв'язання проблеми. За оцінкою строків настання фенофаз розвитку, ми маємо можливість проводити біологічний контроль за ростом і розвитком рослин [2]. Зовнішні морфологічні зміни обумовлюються стадійністю поетапного виконання генетичної програми онтогенезу [4].

Динаміка формування врожаю (залежно від основних складових їх елементів) перебуває у закономірній відповідності етапів органогенезу до фенологічних фаз розвитку [6].

Мета досліджень. Метою проведених досліджень було визначення залежності між елементами технології вирощування (норма висіву, спосіб сівби) і часом проходження рослинами окремих міжфазних періодів. Аналізуючи зв'язки між тривалістю проходження окремих міжфазних періодів і елементами технології, можна значною мірою пояснити варіаційні розбіжності ознак продуктивності в досліджуваних варіантах.

Методика досліджень. У дослідах сівбу ярої твердої пшениці проводили двома способами: рядковим і смуговим із нормами висіву від 4,5 до 6,0 млн/га із кроком градації - 0,5 млн/га. Чотирирічний дослід (2007-2010рр.) проведено за загальноприйнятою методикою методом розщеплених ділянок. Кількість повторень - чотириразова.

Метою досліджень було встановлення впливу смугового способу сівби на час проходження окремих міжфазних періодів порівняно із загальнопоширеним - рядковим способом сівби. Сівбу смуговим способом проводили сівалкою АПП-6 «Фрегат». Конструктивні особливості висівальних апаратів цієї сівалки забезпечували більш рівномірний висів насіння на задану глибину загортання, порівняно 3 рядковим способом, щільний контакт насіння із насіннєвим ложе 3 незруйнованою капілярною структурою; до того ж насіння зверху огорталося пухким шаром грунту з високим показником коефіцієнта структурності.

Результати досліджень. За результатами проведеної оцінки тривалості фенофаз розвитку посівів ярої пшениці залежно від норми висіву насіння та характеру його розподілу по посівній площі встановлено розбіжності, що вказують на різний характер формування посівів, починаючи із самого початку їх становлення.

Тривалість періоду від сівби до фази повних сходів, у середньому, за роки досліджень становила 10 діб за смугового способу сівби і 11 діб - 
за рядкового. Відзначена тенденція спостерігалася щорічно (табл. 1). Найбільша різниця між способами сівби та впливом на даний показник була відзначена у 2007 р. (два дні). Відзначену тенденцію - скорочення періоду від сівби до повних сходів - можна пояснити насамперед більш вирівняною глибиною загортання, що забезпечувалася за смугового способу сівби. За рядкового способу частина насіння висівалася значно глибше від нормативної глибини, внаслідок чого спостерігалася значна диференціація посівів за характером сходів. За смугового способу в результаті значно меншого розсіювання насіння від запланованої глибини заробки фаза повних сходів розпочиналася раніше.

Існує чимало даних, у яких наголошується на негативних наслідках невирівняної сівби за глибиною заробки $[1,3,5]$. Проведені нами спостереження підтверджують цю думку. При визначенні тривалості періоду фази сходів за дії досліджуваних елементів технології вирощування також простежується тенденція до скорочення часу його проходження за смугового способу сівби. Різниця між способами сівби за даним показником становила близько однієї доби. Дана тенденція простежувалася в усі роки досліджень (табл. 2).

Таким чином, завдяки більш вирівняній глибині загортання за смугового способу сівби період від сівби до фази кущіння був, у середньо- му, на дві доби коротший, ніж за рядкового способу, і становив 30 днів. За рядкового способу сівби фаза кущіння у посівах пшениці ярої наставала через 36 днів після закладки досліду у 2007 р. і через 31,29 та 28 днів - у 2008, 2009, 2010 рр. відповідно. За смугового способу сівби фаза кущіння від часу закладки досліду визначалася на 34-й, 30-й, 29-й, 26-й день відповідно у 2007, 2008, 2009 та 2010 роках.

Розтягування періоду від сівби до кущіння це фактично втрата агроресурсу вегетативного періоду розвитку за етапами органогенезу. Інтенсивність розвитку рослин до кущіння - пеpioду, в який рослина вже стає більш підготовленою до погодних змін (насамперед фактора зволоження), має досить важливе значення, поскільки на початку розвитку часто тривалість сприятливого періоду обмежена й кожен день має важливе значення для закладання майбутньої продуктивності посівів.

Для формування високопродуктивних посівів суттєву роль відіграє також фаза кущіння - період, який збігається 3 вичленуванням метомерів колосового стрижня.

Тривалість цього періоду значною мірою визначає характер розвитку і сегментації осі суцвіття. Його подовження за сприятливих погодних умов у цілому підвищує озерненість колосу i створює більш сприятливі умови для формування вищої продуктивності посівів.

\section{1. Тривалість періоду від сівби до фази повних сходів у посівах пшениці ярої твердої за дії досліджуваних елементів технології, днів}

\begin{tabular}{|c|c|c|c|c|c|c|}
\hline Способи сівби & $\begin{array}{c}\text { Норми висі- } \\
\text { ву, млн/га }\end{array}$ & $2007 \mathrm{p}$ & $2008 \mathrm{p}$. & $2009 \mathrm{p}$. & $2010 \mathrm{p}$. & Середнє \\
\hline 1 & 2 & 3 & 4 & 5 & 6 & 7 \\
\hline \multirow{4}{*}{ Рядковий } & 4,5 & 14 & 10 & 11 & 10 & 11 \\
\hline & 5,0 & 14 & 10 & 11 & 10 & 11 \\
\hline & 5,5 & 14 & 10 & 10 & 10 & 11 \\
\hline & 6,0 & 14 & 11 & 12 & 10 & 12 \\
\hline \multirow{4}{*}{ Смуговий } & 4,5 & 12 & 10 & 10 & 9 & 10 \\
\hline & 5,0 & 13 & 10 & 10 & 9 & 10 \\
\hline & 5,5 & 12 & 9 & 10 & 9 & 10 \\
\hline & 6,0 & 13 & 10 & 10 & 9 & 10 \\
\hline \multirow{4}{*}{$\begin{array}{c}\text { Середнє } \\
\text { за нормами висіву }\end{array}$} & 4,5 & 13 & 10 & 11 & 10 & 11 \\
\hline & 5,0 & 14 & 10 & 11 & 10 & 11 \\
\hline & 5,5 & 13 & 10 & 10 & 10 & 11 \\
\hline & 6,0 & 14 & 11 & 11 & 10 & 11 \\
\hline \multirow{2}{*}{$\begin{array}{c}\text { Середнє } \\
\text { за способами сівби }\end{array}$} & рядковий & 14 & 10 & 11 & 10 & 11 \\
\hline & смуговий & 12 & 10 & 10 & 9 & 10 \\
\hline \multicolumn{2}{|c|}{ Середнс по сорту } & 13 & 10 & 11 & 10 & 11 \\
\hline
\end{tabular}


2. Тривалість фази сходів пиениці ярої за дї різних норм висіву та способів сівби, днів

\begin{tabular}{|c|c|c|c|c|c|c|}
\hline Способи сівби & $\begin{array}{c}\text { Норми висі- } \\
\text { ву, млн/га }\end{array}$ & 2007 p. & $2008 \mathrm{p}$. & 2009 p. & 2010 p. & Середнє \\
\hline \multirow{4}{*}{ Рядковий } & 4,5 & 23 & 20 & 19 & 17 & 20 \\
\hline & 5,0 & 22 & 21 & 19 & 17 & 20 \\
\hline & 5,5 & 22 & 21 & 21 & 18 & 21 \\
\hline & 6,0 & 22 & 21 & 21 & 18 & 21 \\
\hline \multirow{4}{*}{ Смуговий } & 4,5 & 22 & 20 & 19 & 17 & 20 \\
\hline & 5,0 & 21 & 20 & 19 & 17 & 19 \\
\hline & 5,5 & 22 & 21 & 19 & 17 & 20 \\
\hline & 6,0 & 22 & 20 & 20 & 18 & 20 \\
\hline \multirow{4}{*}{$\begin{array}{c}\text { Середнє } \\
\text { за нормами висіву }\end{array}$} & 4,5 & 23 & 20 & 19 & 17 & 20 \\
\hline & 5,0 & 22 & 21 & 19 & 17 & 20 \\
\hline & 5,5 & 22 & 21 & 20 & 18 & 21 \\
\hline & 6,0 & 22 & 21 & 21 & 18 & 21 \\
\hline \multirow{2}{*}{$\begin{array}{c}\text { Середнє } \\
\text { за способами сівби }\end{array}$} & рядковий & 22 & 21 & 20 & 18 & 21 \\
\hline & смуговий & 22 & 20 & 19 & 17 & 20 \\
\hline \multicolumn{2}{|c|}{ Середнє по сорту } & 22 & 20 & 20 & 17 & 21 \\
\hline
\end{tabular}

3. Тривалість фази кущіння залежсно від норм висіву та способів сівби на посівах пшениці ярої твердої сорту Харківська-41, днів

\begin{tabular}{|c|c|c|c|c|c|c|}
\hline Способи сівби & $\begin{array}{l}\text { Норми висі- } \\
\text { ву, млн/га }\end{array}$ & 2007 p. & $2008 \mathrm{p}$. & 2009 p. & 2010 p. & Середнє \\
\hline \multirow{4}{*}{ Рядковий } & 4,5 & 15 & 13 & 14 & 13 & 14 \\
\hline & 5,0 & 16 & 12 & 13 & 12 & 13 \\
\hline & 5,5 & 14 & 11 & 13 & 12 & 13 \\
\hline & 6,0 & 13 & 10 & 12 & 11 & 12 \\
\hline \multirow{4}{*}{ Смуговий } & 4,5 & 18 & 13 & 14 & 13 & 15 \\
\hline & 5,0 & 17 & 13 & 14 & 13 & 14 \\
\hline & 5,5 & 17 & 13 & 14 & 13 & 14 \\
\hline & 6,0 & 15 & 12 & 13 & 12 & 13 \\
\hline \multirow{4}{*}{$\begin{array}{c}\text { Середнє } \\
\text { за нормами висіву }\end{array}$} & 4,5 & 17 & 13 & 14 & 13 & 15 \\
\hline & 5,0 & 17 & 13 & 14 & 13 & 14 \\
\hline & 5,5 & 16 & 12 & 14 & 13 & 14 \\
\hline & 6,0 & 14 & 11 & 13 & 12 & 13 \\
\hline \multirow{2}{*}{$\begin{array}{c}\text { Середнє } \\
\text { за способами сівби }\end{array}$} & рядковий & 14 & 11 & 13 & 12 & 12 \\
\hline & смуговий & 17 & 13 & 14 & 13 & 14 \\
\hline \multicolumn{2}{|c|}{ Середнє по сорту } & 15 & 12 & 14 & 13 & 14 \\
\hline
\end{tabular}

Аналіз даних періоду від фази розвитку трьох листків до настання фази виходу в трубку показав, що за смугового способу сівби він був довший і тривав залежно від норм висіву і погодного фактора 12-18 днів (табл. 3), а за рядкового способу сівби цей період був меншим - від 10 до 15 днів. Таким чином, тривалість фази на посівах рядкового способу сівби у середньому була меншою на два дні.

Отже, тривалість періоду від сівби до фази виходу у трубку за обох способів сівби була одна- ковою, незважаючи на встановлені розбіжності по окремих етапах цього періоду розвитку рослин пшениці ярої.

Як за рядкового, так і за смугового способів сівби тривалість указаного періоду розвитку посівів була 45 діб. Розбіжності тривалості фази кущіння, які у середньому за нормами висіву становили два дні, спричинялися передусім затримкою розвитку рослин на початковій стадії, зокрема під час проростання й настання фази кущіння. Внаслідок цього на рядкових посівах поява повних сходів запізнювала- 
ся на один день. Запізнення настання фази повного кущіння також становило один день. За смугового способу сівби, завдяки більш вирівняній глибині загортання насіння, сходи з'явилися дещо дружніше. Відповідно, дружні сходи забезпечували дружніше і прискорене настання фази кущіння. Таким чином, різниця у два дні свідчить: рослини за смугового способу сівби, завдяки більш дружному поетапному розвитку із самого початку проростання, раніше починаються кущитися. Це підтверджує ефективність факторів рослинництва, за якими дотримана рівномірна глибина загортання насіння відповідно до біологічних вимог розвитку рослин пшениці ярої на початку онтогенезу рослин.

Статистична обробка показників із використанням критерію Дункана доводить істотність впливу досліджуваних норм висіву. На рядкових посівах збільшення норми висіву з 4,5 до 6,0 млн/га зменшувало тривалість кущіння в середньому по роках на два дні. Аналогічна тенденція відзначена й на смугових посівах, де, як і на рядкових посівах, тривалість кущіння при збільшенні норми висіву 3 4,5 до 6,0 млн/га за смугового способу зменшувалася на два дні. За обох способів сівби показники тривалості фази кущіння при нормах висіву 4,5 і 6,0 млн/га входили до різних гомогенних груп за ранговим критерієм Дункана. Показники тривалості фенофази кущіння за норм висіву 5,0 і 5,5 млн/га при обох способах сівби утворювали окрему статистичну гомогенну групу. Аналогічну тенденцію відзначено в усі роки досліджень. Лише у 2007 р. встановлено істотну різницю за даним показником за рядкового способу сівби між варіантами, де застосовували но- рми висіву 5,0 та 5,5 млн/га.

Важливо те, що на смугових посівах різниці за тривалістю періоду кущіння між нормами висіву 4,5 i 5,5 млн/га фактично не було. У період із 2008 до 2010 рр. різниці між нормами висіву 4,5; 5,0; 5,5 млн/га не відзначено. Показники тривалості фази кущіння утворювали одну гомогенну групу. Таку тенденцію можна пояснити перевагою смугового способу, який забезпечує білыш рівномірний розподіл насіння як за глибиною заробки, так і по посівній площі, за рахунок чого значно зменшується ценотична напруга між рослинами у посівах.

Отже, за чотири роки досліджень нами встановлено вплив норм висіву та способів сівби на тривалість фази кущіння. Наведений вище аналіз розвитку посівів за фенологічними спостереженнями доводить вагоме значення такого фактора, як норма висіву, а також рівномірності розосередження насіння по площі живлення та за глибиною заробки.

Аналіз тривалості міжфазного періоду «вихід у трубку - цвітіння» показав різницю між досліджуваними показниками стосовно впливу на результативність даного показника. За смугового способу сівби тривалість вказаного міжфазного періоду в середньому за нормами висіву і роками досліджень становила 26 днів, за рядкового - 27. Аналогічна тенденція спостерігалася в усі роки досліджень. Вплив норм висіву відзначено лише на варіантах рядкового способу сівби (табл. 4). Як і на початкових етапах розвитку, більший вплив на мінливість результативності цього показника відзначено за таким фактором, як погодні умови року.

\section{4. Тривалість мізжфазного періоду «вихід у трубку - цвітіння" рослин ярої твердої пшениці} за дї різних норм висіву та способів сівби, днів

\begin{tabular}{|c|c|c|c|c|c|c|}
\hline Способи сівби & $\begin{array}{l}\text { Норми висі- } \\
\text { ву, млн/га }\end{array}$ & 2007 p. & $2008 \mathrm{p}$ & $2009 \mathrm{p}$. & 2010 p. & Середнє \\
\hline \multirow{4}{*}{ Рядковий } & 4,5 & 25 & 30 & 26 & 23 & 26 \\
\hline & 5,0 & 25 & 30 & 27 & 23 & 26 \\
\hline & 5,5 & 26 & 31 & 27 & 24 & 27 \\
\hline & 6,0 & 27 & 32 & 28 & 25 & 28 \\
\hline \multirow{4}{*}{ Смуговий } & 4,5 & 25 & 30 & 26 & 23 & 26 \\
\hline & 5,0 & 26 & 30 & 26 & 24 & 27 \\
\hline & 5,5 & 26 & 30 & 26 & 23 & 26 \\
\hline & 6,0 & 27 & 31 & 27 & 24 & 27 \\
\hline \multirow{4}{*}{$\begin{array}{c}\text { Середнє } \\
\text { за нормами висіву }\end{array}$} & 4,5 & 25 & 30 & 26 & 23 & 26 \\
\hline & 5,0 & 26 & 30 & 27 & 24 & 27 \\
\hline & 5,5 & 26 & 31 & 27 & 24 & 27 \\
\hline & 6,0 & 27 & 32 & 28 & 25 & 28 \\
\hline \multirow{2}{*}{$\begin{array}{c}\text { Середнє } \\
\text { за способами сівби }\end{array}$} & рядковий & 26 & 31 & 27 & 24 & 27 \\
\hline & смуговий & 26 & 30 & 26 & 24 & 26 \\
\hline
\end{tabular}




\section{5. Тривалість міжфазного періоду «початок цвітіння - початок воскової стиглості» рослин пшениці ярої твердої за дії різних норм висіву та способів сівби, днів}

\begin{tabular}{|c|c|c|c|c|c|c|}
\hline Способи сівби & $\begin{array}{c}\text { Норми висі- } \\
\text { ву, млн/га }\end{array}$ & $2007 \mathrm{p}$. & $2008 \mathrm{p}$. & 2009 p. & $2010 \mathrm{p}$. & Середнє \\
\hline \multirow{4}{*}{ Рядковий } & 4,5 & 30 & 31 & 26 & 24 & 28 \\
\hline & 5,0 & 30 & 31 & 26 & 25 & 28 \\
\hline & 5,5 & 30 & 29 & 25 & 22 & 27 \\
\hline & 6,0 & 29 & 28 & 24 & 22 & 26 \\
\hline \multirow{4}{*}{ Смуговий } & 4,5 & 31 & 31 & 27 & 25 & 29 \\
\hline & 5,0 & 31 & 31 & 27 & 24 & 29 \\
\hline & 5,5 & 31 & 30 & 27 & 25 & 28 \\
\hline & 6,0 & 30 & 30 & 26 & 24 & 28 \\
\hline \multirow{4}{*}{$\begin{array}{c}\text { Середнє } \\
\text { за нормами висіву }\end{array}$} & 4,5 & 31 & 31 & 27 & 25 & 29 \\
\hline & 5,0 & 31 & 31 & 27 & 25 & 29 \\
\hline & 5,5 & 31 & 30 & 26 & 24 & 28 \\
\hline & 6,0 & 30 & 29 & 25 & 23 & 27 \\
\hline \multirow{2}{*}{$\begin{array}{c}\text { Середнє } \\
\text { за способами сівби }\end{array}$} & рядковий & 30 & 30 & 25 & 23 & 27 \\
\hline & смуговий & 31 & 31 & 27 & 25 & 29 \\
\hline
\end{tabular}

У результаті досліджень встановлено тенденцію щодо скорочення тривалості міжфазного періоду «вихід у трубку - цвітіння» при зменшенні ценотичної напруги у посівах пшениці ярої й за більш рівномірного розміщення у посівному шарі грунту при нормативній глибині загортання.

Проведені фенологічні спостереження свідчать, що тривалість періоду «цвітіння - воскова стиглість зерна» рослин пшениці твердої ярої за смугового способу сівби в середньому за нормами висіву була довшою на два дні. Така тенденція простежувалася і безпосередньо в роки досліджень (табл. 5). Суттєвіше різниця між способами сівби виявлялася на фоні загущення посівів (за норми висіву 6,0 млн/га). Що стосується норми висіву, то більш виражена різниця ефекту норми висіву була за рядкового способу сівби. Тобто, за рахунок зменшення напруги ценотичної дії між рослинами за розосередженої сівби смуговим способом реакція рослин на загущення посівів проявлялася менше порівняно 3 рядковим способом сівби.

Аналіз результатів досліджень свідчить: на тривалість міжфазного періоду «цвітіння - воскова стиглість» час, коли відбувається зиготогенез, ембріогенез і ендоспермогенез зернівки, значний вплив мають норми висіву та способи сівби - фактори, що визначають площу живлення рослин. Окрім цього позитивний ефект смугового способу сівби полягає також в оптимізації глибини загортання, звуження меж діапазону залягання насіння за глибиною.

Відносно ярої твердої пшениці слід відзначити, що це досить відповідальний період, протягом якого відбувається накопичення поживних речовин в ендоспермі зернівки, формування алейронового шару й виповнення його білком. Саме у цей міжфазний період - від цвітіння до воскової стиглості - у пшениці проходить процес наливу зерната збільшення показників його якості.

Висновки. У результаті проведених досліджень встановлено вплив норм висіву і способів сівби на тривалість проходження міжфазних періодів розвитку рослин пшениці ярої твердої.

Ефект способу сівби на ранніх стадіях обумовлювався насамперед рівномірністю заробки насіння на потрібну глибину, яка забезпечувалася завдяки конструктивним особливостям сошника сівалки АПП - 6 «Фрегат». Ефект норми висіву проявляється 3 фази кущіння, коли починає збільшуватися ценотична напруга у посівах пшениці. Водночас спостерігалася наступна перевага смугового способу, що полягала у значному зниженні ценотичного ефекту в посівах внаслідок збільшення площі живлення під рослинами.

Загальною закономірністю впливу способів сівби та норм висіву на тривалість міжфазного періоду «вихід у трубку - цвітіння» $\epsilon$ його скорочення у результаті послаблення ценотичної напруги при зменшенні норм висіву за смугового способу сівби й, відповідно, збільшення тривалості міжфазного періоду «цвітіння - воскова стиглість» за дії цих же варіантів дослідних факторів. 


\section{БІБЛІОГРАФІЯ}

1. Апрелева М. С. Развитие посевов яровой пшеницы // Тр. Харьковского с.-х. ин-та. - К., - 1959. - T. 18. - C. 34-46.

2. Куперман Ф. М. Биологический контроль за развитием растений на метеорологических станциях (микрофенология) / Ф. М. Куперман, Ю. И. Чирков. - Л., 1970.

3. Ламан H. А. Потенциал продуктивности хлебных злаков. Технологические аспекты реализации / Н. А. Ламан, Б. Н. Янушкевич, К. И. Хмурец. - Л. : Наука и техника, 1987. - 224 с.

4. Методологические указания по исследованию закономерностей формообразования основных элементов продуктивности культурных злаков растений и их возможному использованию в теоретических и практических целях / сост. Г. А. Козлечков, А. М. Данилов, А. Л. Данильченко [и др.] - Новочеркасск, 1984. - Деп. в ВНИИТЭИСХ 23.03.81. - №307. - С. 84.

5. Epandage d'engrais et semis // Fracteurs et machines agricoles. - 1983. - №80. - P. 37-41.

6. Hänsel $H$. Physiologie der Ertragsbildung und die Züchtung auf Ertrag bei Getreide. - // H. Hänsel. Z.für Pflanzenzüchtung, 1965. - P. 54; 97-110. 